\title{
HAK PENSIUN JANDA KEDUA DARI SUAMI YANG BEKERJA SEBAGAI APARATUR SIPIL NEGARA (ASN)
}

\author{
Dian Woro Sawitri, Fifiana Wisnaeni \\ Program Studi Magister Kenotariatan, \\ Fakultas Hukum, Universitas Diponegoro
}

\begin{abstract}
State Civil Apparatus (ASN) according to Article 1 paragraph 1 of Law Number 5 Year 2014 on ASN is a profession for civil servants and government employees with employment agreements working in government agencies. In the case of a Civil Servant or the employee's pension recipient having more than one wife, the widow's pension shall be granted to the wife who was then the longest and uninterruptedly married. The purpose of this study is to know and analyze the legal efforts that can be done by a second widow if not get the right pension from husband who work as ASN. The approach method used in this research is the method of Juridical Normative Approach While Analysis in this Research is Descriptive analitif. The result of this research is the right of pension income to widow more than one person not listed in pension recipients that can be distributed to all legitimate wives and the division is $36 \%$ (divided equally) from minimum $75 \%$ minimum wage according to government regulation but must have the main proof of the legitimate marriage certificate is the marriage certificate / marriage certificate. The legal means that may be filed by the related party (the second widow of ASN) is through the provisions of the Marriage Act through the marriage herbat of the second widow and the related ASN who has passed away.
\end{abstract}

Keywords: Pension Rights, Second Widow, State Civil Apparatus.

\begin{abstract}
Abstrak
Aparatur Sipil Negara (ASN) menurut Pasal 1 ayat 1 Undang-Undang Nomor 5 Tahun 2014 tentang ASN adalah profesi bagi pegawai negeri sipil dan pegawai pemerintah dengan perjanjian kerja yang bekerja pada instansi pemerintah. Dalam hal Pegawai Negeri atau penerima pensiun pegawai pria tersebut beristri lebih dari seorang, maka pensiun janda diberikan kepada istri yang ada waktu itu paling lama dan tidak terputus-putus dinikahnya. Tujuan penelitian ini adalah Untuk mengetahui dan menganalisis upaya hukum yang dapat dilakukan oleh janda kedua apabila tidak memperoleh hak pensiun dari suami yang bekerja sebagai ASN. Metode pendekatan yang digunakan dalam penelitian ini adalah metode pendekatan Yuridis Normatif Sedangkan Analisa dalam Penelitian ini bersifat Deskriptif analitif. Hasil penelitian ini adalah Hak penerimaan pensiun terhadap janda lebih dari satu orang yang tidak terdaftardalam daftar penerima pensiun yaitu dapat dibagikan kesemua istri yang sah dan pembagianya adalah $36 \%$ (dibagi rata) dari minimal $75 \%$ gaji terendah menurut peraturan pemerintah yang berlaku tetapi harus memiliki bukti utama dari pengakuan perkawinan yang sah yaitu akta nikah/ surat nikah.Upaya hukum yang dapat diajukan oleh pihak terkait (janda kedua dari ASN) adalah melalui
\end{abstract}


ketentuan dalam Undang-Undang Perkawinan yaitu melalui itsbat nikah dari janda kedua dan ASN terkait yang telah meninggal dunia.

Kata Kunci : Hak Pensiun, Janda Kedua, Aparatur Sipil Negara.

\section{A. Pendahuluan}

Pemerintah resmi menjalankan Undang-undang Nomor 5 Tahun 2014 tentang Aparatur Sipil Negara, dimana Pengertian Aparatur Sipil Negara yang selanjutnya disingkat ASN diatur dalam Pasal 1 angka 1 "profesi bagi pegawai negeri sipil dan pegawai pemerintah dengan perjanjian kerja yangbekerja pada instansi pemerintah ${ }^{1}$.

Warga Negara Indonesia yang memenuhi syarat tertentu,diangkat sebagai Pegawai ASN secara tetap oleh pejabat pembina kepegawaian untuk mendudukijabatan pemerintahan.ASN mendapatkan salah satu hak berupa pensiun. Pensiun ASN diberikan sebagai Jaminan Hari Tua dan sebagai penghargaan atas jasa-jasa ASN yang telah bekerja dan mengabdi pada pemerintahan. Batas Usia Pensiun (BUP) bagi ASN adalah 58 (lima puluhdelapan) tahun ${ }^{2}$.Hal ini diatur dalam Pasal 90 Undang-undang Nomor 5 Tahun 2014 tentang ASN.Usia 60 (enam puluh) tahun bagiASNpejabat Pimpinan Tinggi.

Terkait Pegawai ASN yang meninggal dunia ini, dalam Pasal 16 ayat (1) Undang-Undang Nomor 11 Tahun 1969 mengatur:

Apabila Pegawai Negeri atau penerima pensiun pegawai meninggal dunia, maka istri (istri-istri) nya untuk pegawai Negeri pria atau suaminya untuk Pegawai Negeri Wanita, yang sebelumnya telah terdaftar pada kantor Urusan Pegawai, berhak menerima pensiun janda atau pensiun duda.

Sementara untuk istri kedua dari pernikahan dengan suami maka harus didaftarkan ke Kepala Kantor Urusan Pegawai untuk Taspen.Pasal 16 ayat (2) UU 11/1969 menyebutkan bahwa apabila Pegawai Negeri atau penerima

\footnotetext{
${ }^{1}$ S.Nurbaya, Kebijakan Otonomi Daerah Di Indonesia (Jakarta, 2002).

${ }^{2}$ Alam Nur dan Harun Harno, 'Himpunan Undang - Undang Kepegawaian Dan Reformasi Administrasi Publik' (Jakarta: Raja Grafindo Persada, 2005), p. 55.
} 
pensiun pegawai yang beristeri/bersuami meninggal dunia, sedangkan tidak ada istri/suami yang terdaftar sebagai yang berhak menerima pensiun janda/duda, maka dengan menyimpang dari ketentuan pada Pasal 16 ayat (1)UU 11/1969, pensiun janda/duda diberikan kepada istri/suami yang ada pada waktu ia meninggal dunia. Dalam hal Pegawai Negeri atau penerima pensiun pegawai pria tersebut beristri lebih dari seorang, maka pensiun janda diberikan kepada istri yang ada waktu itu paling lama dan tidak terputus-putus dinikahnya.

Namun apabila dari perkawinan sebelumnya ada anak, maka anak dari perkawinan tersebut juga berhak atas bagian dari pensiun janda, sebagaimana diatur dalamPasal 18 ayat (2) UU 11/1969:

Apabila pegawai negeri pria atau penerima pensiun pegawai pria meninggal dunia, sedangkan ia mempunyai isteri (isteri-isteri) yang berhak menerima pensiun janda/bagian pensiun janda di samping anak (anak-anak) dari isteri (isteri-isteri) yang telah meninggal dunia atau telah cerai, maka bagian pensiun janda diberikan kepada masing-masing isteri dan golongan anak (anak-anak) seayah seibu termaksud.

Berdasarkan Pasal 3 Huruf d Undang - Undang No.11 Tahun 1969 yang dimaksud dengan anak adalah anak kandung yang sah atau anak kandung/anak yang disahkan menurut Undang-Undang Negara dari pegawai negeri, penerima pensiun, atau penerima pensiun janda/duda.

Atas dasar latar belakang tersebut di atas, maka yang menjadi perumusan masalah adalahBagaimanahak pensiun janda kedua dari suami yang bekerja sebagai Aparatur Sipil Negara (ASN) baik yang belum maupun sudah diberikan hak yang sama berdasarkan Undang-Undang Nomor 5 Tahun 2014 tentang Aparatur Sipil Negara serta Bagaimana upaya hukum yang dapat dilakukan oleh janda kedua apabila tidak ada hak pensiun dari suami yang bekerja sebagai Aparatur Sipil Negara (ASN).

\section{B. Metode}


Penelitian ini menggunakan yuridis Normatif, pendekatan normatif dapat meliputi pendekatan konseptual, pendekatan undang-undang, pendekatan kasus, dan pendekatan perbandingan ${ }^{3}$.

Metode penelitian dengan teknik pendekatan ini maksudnya penelitian yang mengacu pada studi kepustakaan yang ada ataupun terhadap data sekunder yang digunakan. Sedangkan bersifat normatif maksudnya penelitian hukum yang bertujuan untuk memperoleh pengetahuan normatif tentang hubungan antara satu peraturan dengan peraturan lain ${ }^{4}$.

\section{Hasil Dan Pembahasan}

1. Hak Pensiun Janda Kedua Dari Suami Yang Bekerja Sebagai Aparatur Sipil Negara (ASN) Baik Yang Belum atau Sudah Diberikan Hak Yang Sama Berdasarkan Undang-Undang Nomor 5 Tahun 2014

Undang-Undang tentang ASN tidak serta merta menghapus UndangUndang No. 11 Tahun 1969 tentang Pensiun Pegawai dan Pensiun Janda/Duda Pegawai.Berdasarkan aturan peralihan Pasal 130 Undang-Undang No. 5 Tahun 1969, UU ASN tidak mengatur ketentuan hak janda kedua.Tetapi berdasar Peraturan Peralihan UU ASN ini, disebutkan bahwa janda kedua diakui keberadaan haknya.

Ketentuan Undang-Undang ASN tidak serta merta menghapus UndangUndang 11 tahun 1969 berdasarkan aturan peralihan Pasal 130 UndangUndang ASN, tidak menghapus hak janda kedua tetapi berdasarkan Pasal 130 Undang-Undang ASN disebutkan bahwa:

Pada saat Undang-Undang ini mulai berlaku, Undang-Undang Nomor 11 Tahun 1969 tentang Pensiun Pegawai dan Pensiun Janda/Duda Pegawai (Lembaran Negara Republik Indonesia Tahun 1969 Nomor 42, Tambahan Lembaran Negara Republik Indonesia Nomor 2906) dan peraturan pelaksanaannya tetap berlaku sampai ditetapkannya peraturan pelaksanaan dari Undang-Undang ini yang mengatur mengenai program pension PNS.

\footnotetext{
${ }^{3}$ Syamsuddin, Operasionalisasi Penelitian Hukum (Jakarta: PT. Raja Grafindo, 2007).

${ }^{4}$ AshsHofa Burhan, Metode Penelitian Hukum (Jakarta: Rineka Cipta, 2004).
} 
ASN yang diangkat dapat diserahi tugas, baik berupa tugas dalam suatu jabatan negeri maupun tugas negara lainnya.Ada perbedaan tugas negeri dan negara lainnya.Dimaksudkan dengan tugas dalam jabatan negeri apabila yang dimaksudkan diberi jabatan dalam bidang eksekutif, maupun yudikatif yang ditetapkan berdasarkan peraturan perundang-undangan yang berlaku.

Pasal 16 ayat (2) UU 11/1969 menyebutkan bahwa apabila Pegawai Negeri atau penerima pensiun pegawai yang beristeri/bersuami meninggal dunia, sedangkan tidak ada istri/suami yang terdaftar sebagai yang berhak menerima pensiun janda/duda, maka dengan menyimpang dari ketentuan pada Pasal 16 ayat (1) UU 11/1969, pensiun janda/duda diberikan kepada istri/suami yang ada pada waktu ia meninggal dunia. Dalam hal ASN atau penerima pensiun pegawai pria tersebutberistri lebih dari seorang, maka pensiun janda diberikan kepada istri yang ada waktu itu paling lama dan tidak terputus-putus dinikahnya.

Apabila dari perkawinan sebelumnya ada anak, maka anak dari perkawinan tersebut juga berhak atas bagian dari pensiun janda, sebagaimana diatur dalam Pasal 18 ayat (2) UU 11/1969:

Apabila pegawai negeri pria atau penerima pensiun pegawai pria meninggal dunia, sedangkan ia mempunyai isteri (isteri-isteri) yang berhak menerima pensiun janda/bagian pensiun janda di samping anak (anak-anak) dari isteri(isteri-isteri) yang telah meninggal dunia atau telah cerai, maka bagian pensiun janda diberikan kepada masing-masing isteri dan golongan anak (anak-anak) seayah seibu termaksud.

Yang dimaksud dengan anak adalah anak kandung yang sah atau anak kandung/anak yang disahkan menurut Undang-undang Negara dari pegawai negeri, penerima pensiun, atau penerima pensiun janda/duda.

Pada prakteknya pensiun dapat dibagikan kesemua istri yang sah dan pembagianya adalah 36\% (dibagi rata) dari minimal $75 \%$ gaji terendah menurut peraturan pemerintah yang berlaku (terlampir daftar besarnya gaji dan pensiun menurut PP No.25 tahun 2013) ini terdapat seperti ini dengan pendaftaran salah seorang janda lain dari pegawai negeri tersebut yang 
mendaftarkan setelah pegawai negeri tersebut meninggal sehingga bukti utama daripengakuan perkawinan yang sah adalah akta nikah/ surat nikah.

Pada prakteknya pensiun dapat dibagikan kesemua istri yang sah dan pembagianyaadalah 36\% (dibagi rata) dari minimal $75 \%$ gaji terendah menurut peraturan pemerintah yangberlaku (terlampir daftar besarnya gaji dan pensiun menurut PP No.25 tahun 2013).Mengenai upaya pemerolehan hak bagi janda kedua pegawai ASN dapat diketahui dalam yurisprudensi bagi si isteri dan putusan Mahkamah Agung tentang Hak Waris.

\section{Yurisprudensi}

Yurisprudensi Mahkamah Agung RI No. 1776 K/Pdt/2007tanggal 28 Juli 200b bahwa Perkawinan Tjia Mei Joeng dengan Liong Tjung Tjen yang dilakukan secara adat dan tidak dicatatkan pada Catatan Sipil dipandang tetap sah dan Penggugat harus dinyatakan sebagai janda Liong Tjung Tjen.

Upaya perlindungan hak dan keadilan bagi anak yang lahir dari perkawinan yang tidak dicatatkan antara PNS laki-laki dengan istri keduanya adalah mengacu Undang-undang Nomor 23 Tahun 2002 Tentang Perlindungan Anak, dalam Pasal 5 dikatakan bahwa sebagai identitas diri dan status kewarga negaraan dari seorang anak, maka setiap anak berhak atas suatu nama dan identitas diri itu harus diberikan sejak kelahirannya yang dituangkan dalam akta kelahiran. Pembuatan akta kelahiran itu sendiri merupakan tanggung jawab pemerintah Pasal 28 ayat (1) Undang-undang Nomor 23 Tahun 2002 Tentang Perlindungan Anak, karena didasarkan pada surat keterangan dari orang yang menyaksikan dan/atau membantu proses kelahiran.

\section{PutusanMahkamah Konstitusi}

Mahkamah Konstitusi (MK) melalui putusan Mahkamah Konstitusi No. 46/PUU-VIII/2010 tentang pengujian pasal 43 ayat (1) UU Perkawinan menyatakan anak yang lahir di luar kawin mempunyai hubungan hukum dengan ayah biologis, tak lagi hanya kepada ibu dan keluarga ibu. Selain itu, konsekuensi dari tidak adanya hubungan antara ayah dan anak secara hukum juga berakibat anak luar kawin tidak mendapat warisan dari ayah biologisnya. 
Putusan Mahkamah Konstitusi RI Nomor 46/PUU-VIII/2010 tanggal 27 Pebruari 2012 lahir karena adanya permohonan yudisial review yang diajukan oleh $\mathrm{Hj}$. Aisyah Mokhtar dan anaknya yang bernama Muhammad Iqbal Ramadhan Moerdiono terhadap ketentuan Pasal 2 ayat (2) dan Pasal 43 ayat (1) Undangundang Nomor 1 Tahun 1974 tentang Perkawinan, dimana Moerdiono sebagai seorang suami yang telah beristri menikah kembali dengan istrinya yang kedua bernama $\mathrm{Hj}$. Aisyah Mokhtar secara syari'at Islam dengan tanpa dicatatkan dalam register Akta Nikah, oleh karena itu ia tidak memiliki Buku Kutipan Akta Nikah, dan dari pernikahan tersebut lahir seorang anak laki-laki yang bernama Muhammad Iqbal Ramdhan Bin Moerdiono.

Mahkamah Konstitusi berpendapat mengenai ketentuan Pasal 2 ayat (2) UU Nomor 1 Tahun 1974 tentang pencatatan perkawinan bahwa sesuai penjelasan umum angka 4 huruf b UU Nomor 1 Tahun 1974 .

Mahkamah Konstitusi menyimpulkan (1) pencatatan perkawinan bukan faktor yang menentukan sahnya perkawinan (2) pencatatan merupakan kewajiban administrasi yang diwajibkan berdasarkan perundangundangan.Kewajiban kewajiban administrasi tersebut dapat dilihat dari dua prespektif, yaitu ; pertama dari prespektif negara, pencatatan dimaksud diwajibkan dalam rangka memenuhi fungsi negara untuk memberikan jaminan perlindungan, pemajuan, penegakan dan pemenuhan hak-hak asasi manusia yang bersangkutan yang merupakan tanggung jawab negara dan harus dilakukan sesuai prinsip negara hukum sebagaimana yang dimuat pada Pasal 281 ayat 4 dan ayat (5) UUD 1945.

Tidak terkecuali anak yang dilahirkan dari PNS laki-laki dengan istri keduanya yang tidak dicatatkan. Hak anak berdasarkan Keputusan Mahkamah Agung dan Undang-Undang Perlindungan anak tersebut, maka anak tersebut mempunyai hak keperdataan yang sama dengan anak yang dilahirkan dari perkawinan yang dicatatkan setelah melalui pencatatan berupa pembuktian secara ilmu pengetahuan dan teknologi. 


\section{Upaya Hukum Yang Dapat Dilakukan Oleh Janda Kedua Oleh Janda Kedua Apabila Tidak Hak Pensiun Dari Suami Yang Bekerja Sebagai Aparatur Sipil Negara (ASN)}

Upaya hukum pertama yang dapat dilakukan untuk mendapatkan pengakuan negara bagi perkawinan yang tidak dicatatkan ádalah melalui pengajuan penetapan nikah (itsbat nikah).Esensi Itsbat nikah adalah perkawinan yang semula tidak dicatatkan menjadi tercatat dan disahkan oleh negara serta memiliki kekuatan hukum. Itsbat nikah merupakan istilah barudalam fiqh munakahat, yang secara harfiah berarti "penetapan”, atau "pengukuhan" nikah. Secara substansial konsep ini difungsikan sebagai ikhtiar agar perkawinan tercatat dan mempunyai kekuatan hukum. Dasar Itsbat nikah KHI Pasal 7;

a. Perkawinan hanya dapat dibuktikan dengan Akta Nikah yang dibuat oleh Pegawai Pencatat Nikah.

b. Dalam hal perkawinan tidak dapat dibuktikan dengan Akta Nikah, dapat diajukan itsbat nikahnya ke Pengadilan Agama.

c. Itsbat nikah yang dapat diajukan ke Pengadilan Agama terbatas

d. Mengenai hal-hal yang berkenaan dengan:

1) Adanya perkawinan dalam rangka penyelesaian perceraian;

2) Adanya keraguan tentang sah atau tidaknya salah satu syarat perkawinan;

3) Adanya perkawinan yang terjadi sebelum berlakunya UU No1/1974;

4) Perkawinan yang dilakukan oleh mereka yang tidak mempunyai halangan perkawinan menurut UU No 1/1974.

e. Yang berhak mengajukan permohonan itsbat nikah ialah suami atauistri, anak-anak mereka, wali nikah dan pihak yang berkepentingan dengan perkawinan itu.

Hakim Agung, Prof Muchsin menyatakan, itsbat nikah merupakan perkara yang tidak mengandung unsur sengketa alias voluntair.PA memiliki kewenangan itu dengan syarat bila dikehendaki oleh UU. Prinsipnya pengadilan tidak mencari-cari perkara melainkan perkara itu telah menjadi 
kewenangannya karena telah diberikan UU.Pasal 7 KHI ternyata memberi PA kompetensi absolut yang sangat luas terhadap itsbat ini ${ }^{5}$.

Sementara untuk mendapatkan pengesahan anak yang dilahirkan dari perkawinan siri juga harus disertakan bersamaan dengan pengajuan Itsbat nikah agar mendapat penetapan yang sama dengan pengesahan nikah orang tuanya. Menurut Andi Syamsu Alam, jika anak yang lahir tidak dapat diakui oleh Catatan Sipil sebagai anak yang lahir dari perkawinan yang sah, perlu di pertimbangkan secara arif karena banyak daerah tidak mau menerima jika anak tersebut dinyatakan lahir dari seorang ibu dan tidak di cantumkan siapa nama bapaknya.

Pasal 44 UU Perkawinan dan Pasal 102 KHI tentang hak pengingkaran anak yang dikandung istri oleh laki-laki.Pada dasarnya hanya perempuanlah yang mengetahui benih siapa yang dikandung.Namun ketentuan ini berpotensi mendiskriminasi dan memojokkan perempuan karena memberikan previlage pada laki-laki untuk mengingkari. Pembuktian bahwa anak yang dikandung adalah anak suami memerlukan usaha yang tidak mudah bagi perempuan yang dapat menempatkan dia pada keputusan ${ }^{6}$.

Upaya hukum lain bisa ditempuh berkaitan dengan pembuktian identitas si anak, meskipun Undang-Undang No. 1 tahun 1974 tentang Perkawinan dan Undang-Undang Perlindungan Anak mensyaratkan adanya akte kelahiran dalam pembuktian asal-usul anak, hal tersebut tidaklah mutlak. Beban pembuktian asal-usul dan identitas anak hasil perkawinan siri terletak pada si Ibu dan mereka-mereka yang mengetahui persis adanya perkawinan siri antara si Ibu dan si Bapak anak tersebut.Akan lebih baik dan akurat, jika bisa membuktikan adanya hubungan darah antara sianak dengan orangtuanyamelalui uji DNA. (tapi ini biayanya sangat mahal).

\section{Simpulan}

Hak penerimaan pensiun terhadap janda lebih dari satu orang yang tidak terdaftardalam daftar penerima pensiun berdasarkan ketentuan UndangUndang ASN tidak serta merta menghapus Undang-Undang 11 tahun 1969

\footnotetext{
${ }^{5}$ Andi Syamsu Alam, Beberapa Permasalahan Hukum diLingkungan Uldilag, 2009.

${ }^{6}$ Ismail Hasani, Referensi Bagi Hakim Peradilan Agama Tentang Kekerasan Dalam Rumah Tangga (Jakarta, 2008).
} 
berdasarkan aturan peralihan Pasal 130 Undang-Undang ASN, tidak menghapus hak janda kedua tetapi berdasarkan Pasal 130 Undang-Undang ASN. Istri yang sah dan pembagianya adalah 36\% (dibagi rata) dari minimal $75 \%$ gaji terendah menurut peraturan pemerintah yang berlaku tetapi harus memiliki bukti utama dari pengakuan perkawinan yang sah yaitu akta nikah/ surat nikah, tetapi tidak semua pegajuan untuk penerimaan pensiun disetujui karena harus melaluipertimbangan - pertimbangan khusus yaitu mengenai faktor kelayakan untukmemberikan pensiun tersebut kepada janda lebih dari satu orang disebabkanbesaran dari pensiun tersebut, jika dibagikan menjadi lebih dari satu akan menjadisangat kecil dan tidak bisa menghidupi dengan layak maka ada juga beberapayang tidak disetujui.

Upaya hukum yang dapat dilakukan oleh janda kedua dari ASN untuk mendapatkan pengakuan negara bagi perkawinan yang tidak dicatatkan ádalah melalui pengajuan penetapan nikah (itsbat nikah) dimana perkawinan yang semula tidak dicatatkan menjadi tercatat dan disahkan oleh negara serta memiliki kekuatan hukum.Dasar Itsbat nikah adalah KHI Pasal 7.Sementara untuk mendapatkan pengesahan anak yang dilahirkan dari perkawinan siri juga harus disertakan bersamaan dengan pengajuan Itsbat nikah. Upaya yang lain dapat ditempuh dengan pelampiran akta kelahiran dari si anak. Di samping itu pembuktian yang lebih valid terkait anak adalah melalui tes DNA.

\section{DAFTAR PUSTAKA}

Alam, Andi Syamsu. (2009). Beberapa Permasalahan Hukum diLingkungan Uldilag

Burhan, AshsHofa. (2004). Metode Penelitian Hukum Jakarta: Rineka Cipta

Harno, Alam Nur dan Harun. (2005). 'Himpunan Undang - Undang Kepegawaian Dan Reformasi Administrasi Publik’ Jakarta: Raja Grafindo Persada.

Hasani, Ismail. (2008) Referensi Bagi Hakim Peradilan Agama Tentang Kekerasan Dalam Rumah Tangga. Jakarta.

S. Nurbaya. (2002). Kebijakan Otonomi Daerah Di Indonesia. Jakarta. 
Syamsuddin. (2007). Operasionalisasi Penelitian Hukum. Jakarta: PT. Raja Grafindo. 